\title{
Investigation of the Best Saccharomyces cerevisiae Growth Condition
}

\author{
Roshanak Salari ${ }^{1}$, Rosita Salari ${ }^{2}$
}

${ }^{1}$ Ph.D. of Drug Control, Assistant Professor, Department of Traditional Persian Pharmacy, School of Persian and Complementary Medicine, Mashhad University of Medical Sciences, Mashhad, Iran

${ }^{2} \mathrm{Ph}$.D. of Food Science and Technology, Food and Drug Administration, Mashhad University of Medical Sciences, Mashhad, Iran

\section{Type of article: Original}

\begin{abstract}
Introduction: Saccharomyces cerevisiae is known as one of the useful yeasts which are utilized in baking and other industries. It can be easily cultured at an economic price. Today the introduction of safe and efficient carriers is being considered. Due to its generally round shape, and the volume that is enclosed by its membrane and cell wall, it is used to encapsulate active materials to protect them from degradation or to introduce a sustained release drug delivery system. Providing the best conditions in order to achieve the best morphological properties of Saccharomyces cerevisiae as a carrier.

Methods: In this research, the most suitable growth condition of yeast cells which provides the best size for use as drug carriers was found by a bioreactor in a synthetic culture medium. Yeast cell reproduction and growth curves were obtained, based on pour plate colony counting data and UV/Visible sample absorption at $600 \mathrm{~nm}$. Yeast cell growth patterns and growth rates were determined by Matlab mathematical software.

Results: Results showed that $\mathrm{pH}=4$ and dissolving oxygen (DO) $5 \%$ was the best condition for yeast cells to grow and reproduce. This condition also provided the largest size $(2 \times 3 \mu)$ yeast cells.

Conclusion: Owing to the yeast cells' low-cost production and their structural characteristics, they could be used as potent drug carriers.

Funding: This work was supported by a grant from the Vice Chancellor of Research of Mashhad University of Medical Sciences.

Keywords: Carrier, Growth, Mathematics, Saccharomyces cerevisiae yeast cells
\end{abstract}

\section{Introduction}

The name Saccharomyces cerevisiae is composed of two parts: The first part "Saccharo" means "sugar fungus" in Latinized Greek while the second part "cerevisiae" means "of beer". S. cerevisiae is known as one of the useful yeasts which are utilized in baking and other industries. It is used as a eukaryotic model organism in biological studies, because it can easily be cultured. This organism carries out the most common type of fermentation. It has a round to ovoid shape and it reproduces by a budding mechanism $(1,2)$. The yeast cells can grow in haploid and diploid forms. Haploid cells indicate a simple mitosis life cycle that, under stressful conditions will die. Diploid cells, like the haploid ones, show the mitosis life cycle, but under high stress situations, enter the meiosis life cycle and produce four haploid spores. Their doubling time is approximately 90 min (3-6). S. cerevisiae can grow aerobically and anaerobically. Its ability to use different sugars depends on which way it grows. If it grows aerobically, galactose and fructose are the best fermenting sugars. All strains require nitrogen and phosphorus sources to grow. To prepare nitrogen, they consume ammonia and urea. They use dihydrogen phosphate as a source of phosphorus. They also need sulfur and various metals such as magnesium for optimum growth. Due to gender differentiation, yeast cells have two mating types: a, and $\alpha$. Two haploid yeast cells of different types can mate with each other. In this situation mating leads to genetic recombination. Almost all the yeasts have buds. As the cells

\section{Corresponding author:}

Dr. Rosita Salari, Food and Drug Administration, Mashhad University of Medical Sciences, Mashhad, Iran.

Tel: +989151079951, Email: r_salari2001@yahoo.com

Received: June 29, 2016, Accepted: September 22, 2016, Published: January 2017

iThenticate screening: August 28, 2016, English editing: October 10, 2016, Quality control: November 28, 2016

(C) 2017 The Authors. This is an open access article under the terms of the Creative Commons Attribution-NonCommercialNoDerivs License, which permits use and distribution in any medium, provided the original work is properly cited, the use is non-commercial and no modifications or adaptations are made. 
grow, the buds grow too until they become mature. They then separate and leave their parents (7). The $S$. cerevisiae yeast cell can be employed as an efficient carrier due to its food-grade and low-cost characteristics. S. cerevisiae is made up of an external thick cell wall which comprises a beta-glucan network and a small amount of chitin associated with a mannoprotein layer. These cell wall properties cause a yeast cell to be a sustained release type carrier. The mechanical strength of the yeasts' structures allows them to load various active materials (8-10). Several experiments in various conditions were carried out in order to improve yeast cell numbers and sizes for use as carriers. Many growth curves have been applied to model biological growth. The logistic growth equation is the most known and efficient model. Different extended growth equations originate from this model according to its restrictions and limitations. The Richard growth equation is one of the extended models which showed the highest correlation with our data (11-15).

\section{Material and Methods}

\subsection{Culture of yeast cells}

S. cerevisiae was provided by the industrial research organization, Tehran, PTCC 5269. Bioreactor (Winpact, FS-01A series (double jacketed vessel)) was used to culture the yeast cells. Bioreactor was applied, to establish the best environmental conditions for the yeasts to grow. It was composed of three parts: controller, gas mixer and gas analyzer. The bioreactor vessel (3 liters) was filled by 2 liters synthetic culture medium $\left(10 \mathrm{~g} \mathrm{KH}_{2} \mathrm{PO}_{4}, 4 \mathrm{~g}\right.$ $\left(\mathrm{NH}_{4}\right)_{2} \mathrm{SO}_{4}, 0.8 \mathrm{~g} \mathrm{MgSO}_{4}, 2 \mathrm{~g}$ yeast extract, $10 \mathrm{~g}$ glucose) (Merck). Three $\mathrm{ml}$ Suspension of yeast cells $\left(10^{8} \mathrm{cfu} / \mathrm{ml}\right)$ in physiologic serum was added to the vessel. The temperature was set at $30^{\circ} \mathrm{C}$ and the culture medium was stirred by the rate of $200 \mathrm{rpm}$. The bioreactor contains a double jacket vessel. The water which circulates around the vessel, between the two jackets, helps the culture medium to maintain its temperature. The temperature of water which circulates around the jacket should be $10-15{ }^{\circ} \mathrm{C}$ lower than the temperature of synthetic culture medium. Previously, growth of $S$. cerevisiae was optimized (16). In the present research, the effects of two parameters of synthetic medium ( $\mathrm{pH}$ and percentage of dissolving oxygen (DO)) in nine situations on $S$. cerevisiae growth rate were studied. Culture medium $\mathrm{pH}$ was adjusted to 4,5 and 6 by HCl $1 \mathrm{M}$ and the percentage of DO was adjusted to 5, 10 and $15 \%$ by gas mixer.

\subsection{Determination of yeast cell growth curves}

Growth of the yeast cells in each condition was defined by colony counting of the fourth diluted plate by colony counter (acolyte (symbiosis)). One milliliter of culture medium was diluted about $10^{-1}$ times with physiologic serum four times and the dilutions were introduced to four separate TSA plates. In addition, UV/Visible (CECIL 9000) absorption of culture medium samples at $600 \mathrm{~nm}$ in 0 to 13 hours were obtained, to plot the common growth curve of microorganisms which were composed of lag, log, stationary and decline phases. Yeast cell growth patterns and growth rates were evaluated by Matlab mathematical software.

\subsection{Determination of yeast cell size}

Size of the yeast cell in the log phase was measured each hour for up to 10 hours by light microscopy and the mean size was determined. If the yeast cell is used as a carrier to load the active materials, its size should be appropriate enough.

\subsection{SEM images}

Scanning electron microscopy (Oxford Company, S-360) was used to study the morphological shape of yeast cells in $\mathrm{pH}=4$ and $\mathrm{DO} 5 \%$. The cells were embedded in paraffin, sectioned, de-paraffined, and sputter-coated with gold.

\section{Results}

\subsection{Determination of yeast cell growth}

Growth curves of the yeast cells were studied in nine situations ( 3 different amounts of $\mathrm{pH} \times 3$ different amounts of percentage DO) (Figures 1-2). Matlab mathematical software was used to design an equation for description of the growth pattern of the yeast cells based on colony counting $\left(\mathrm{CFU} / \mathrm{ml} \times 10^{8}\right)$ (Y axis) against time (h) $(\mathrm{X}$ axis) in $\mathrm{pH}=4$ and DO 5\% which was the best condition. The yeast cell growth curve $(\mathrm{pH}=4$ and $\mathrm{DO} 5 \%)$ based on colony counting was fitted by the Richard equation to estimate the maximum growth rate (Figure 3). The $\mathrm{Y}$ and $\mathrm{X}$ axes showed maximum growth rate and time $(\mathrm{h})$, respectively.

\subsection{Determination of yeast cell size}

Light microscopy was applied to measure the mean size of yeast cells in the $\mathrm{pH}=4$ and $\mathrm{DO} 5 \%$ condition, (Figure 4): 


\subsection{SEM images}

The SEM image of yeast cells in $\mathrm{pH}=4$ and DO $5 \%$ condition is shown in Figure 5.

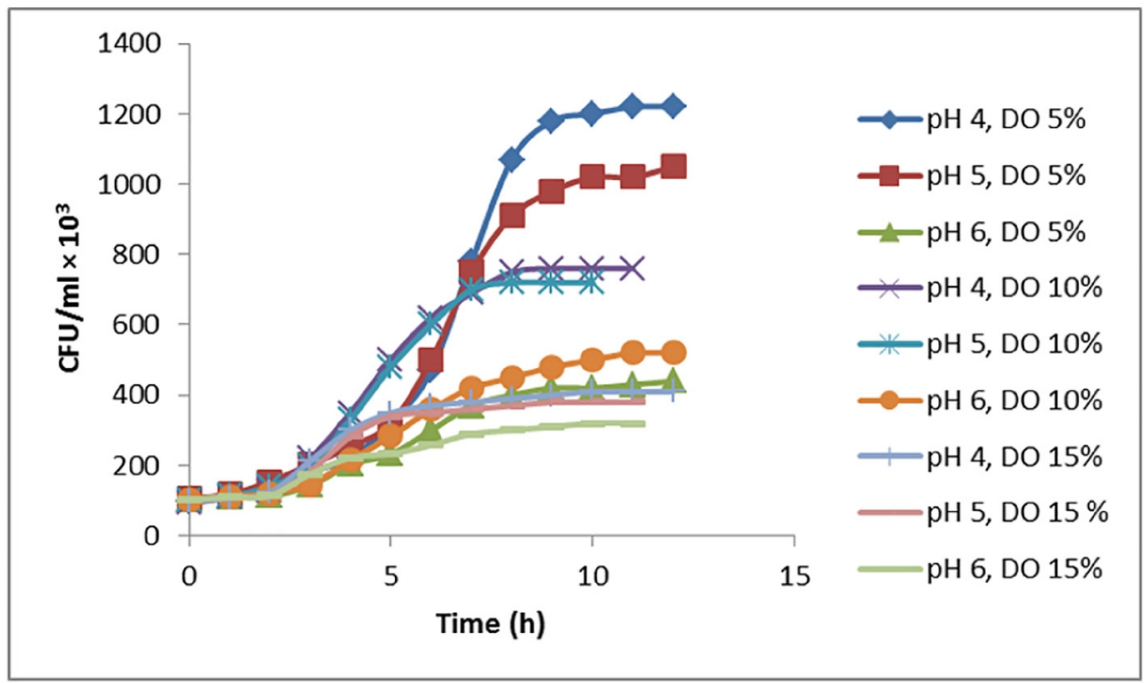

Figure 1. Growth curves of Saccharomyces cerevisiae based on colony counting

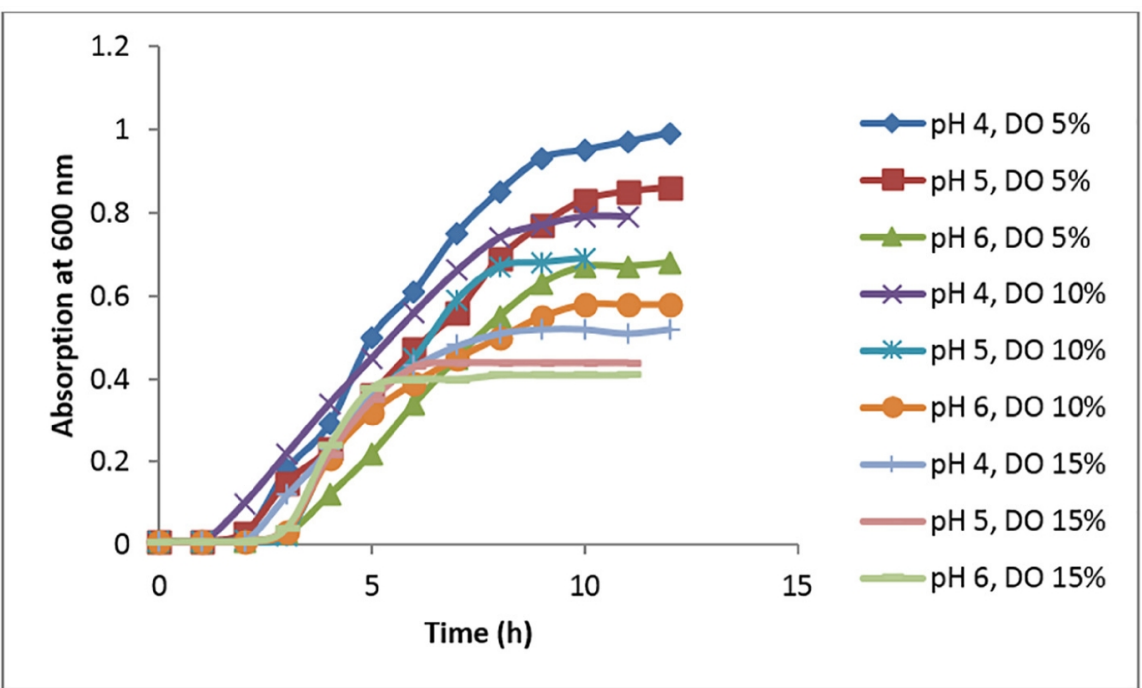

Figure 2. Growth curves of Saccharomyces cerevisiae based on UV/Visible absorptions

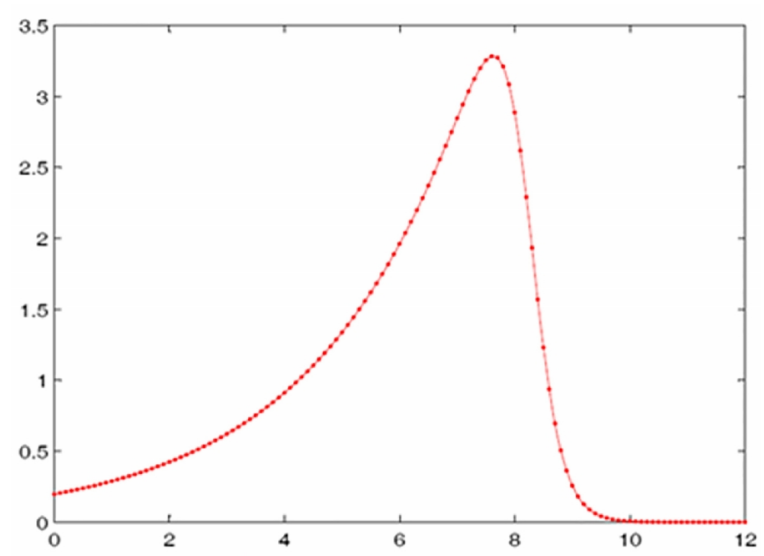

Figure 3. Growth rate curve of Saccharomyces cerevisiae in $\mathrm{pH}=4$ and $\mathrm{DO} 5 \%$ 


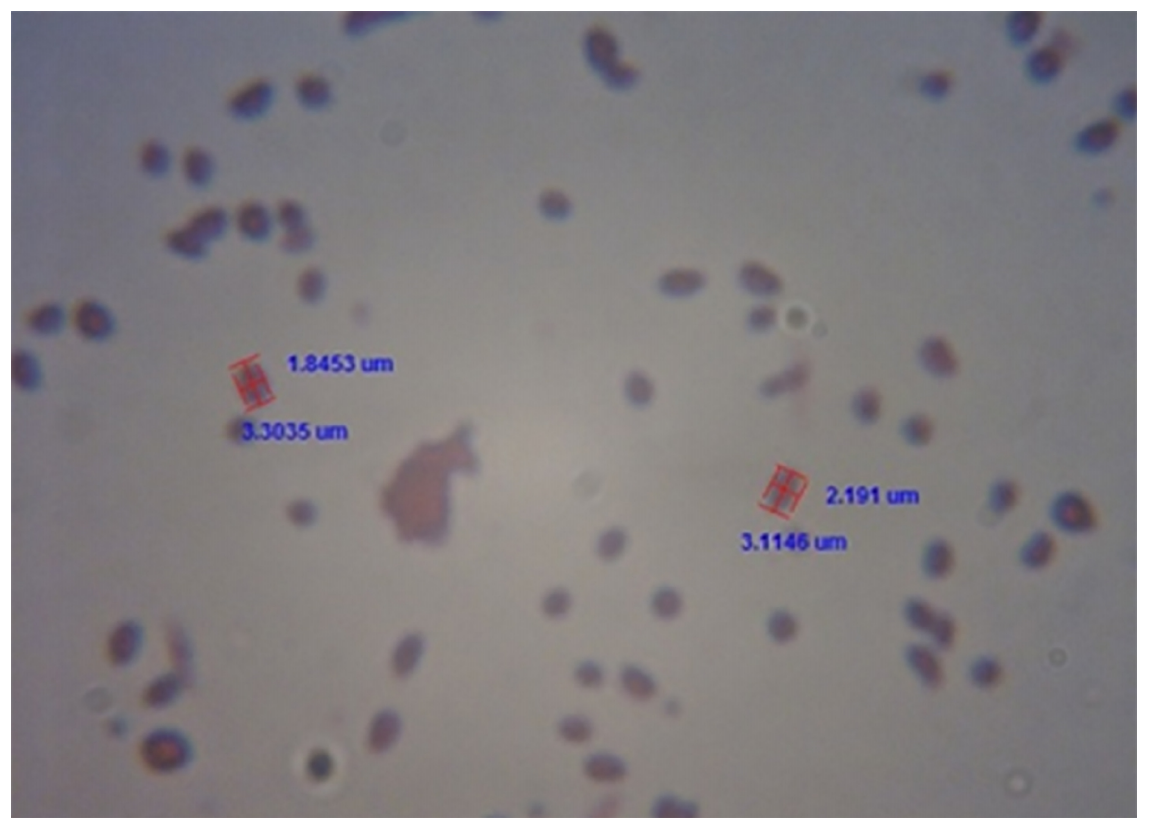

Figure 4. Light microscopy image of Saccharomyces cerevisiae in $\mathrm{pH}=4$ and $\mathrm{DO} 5 \%$

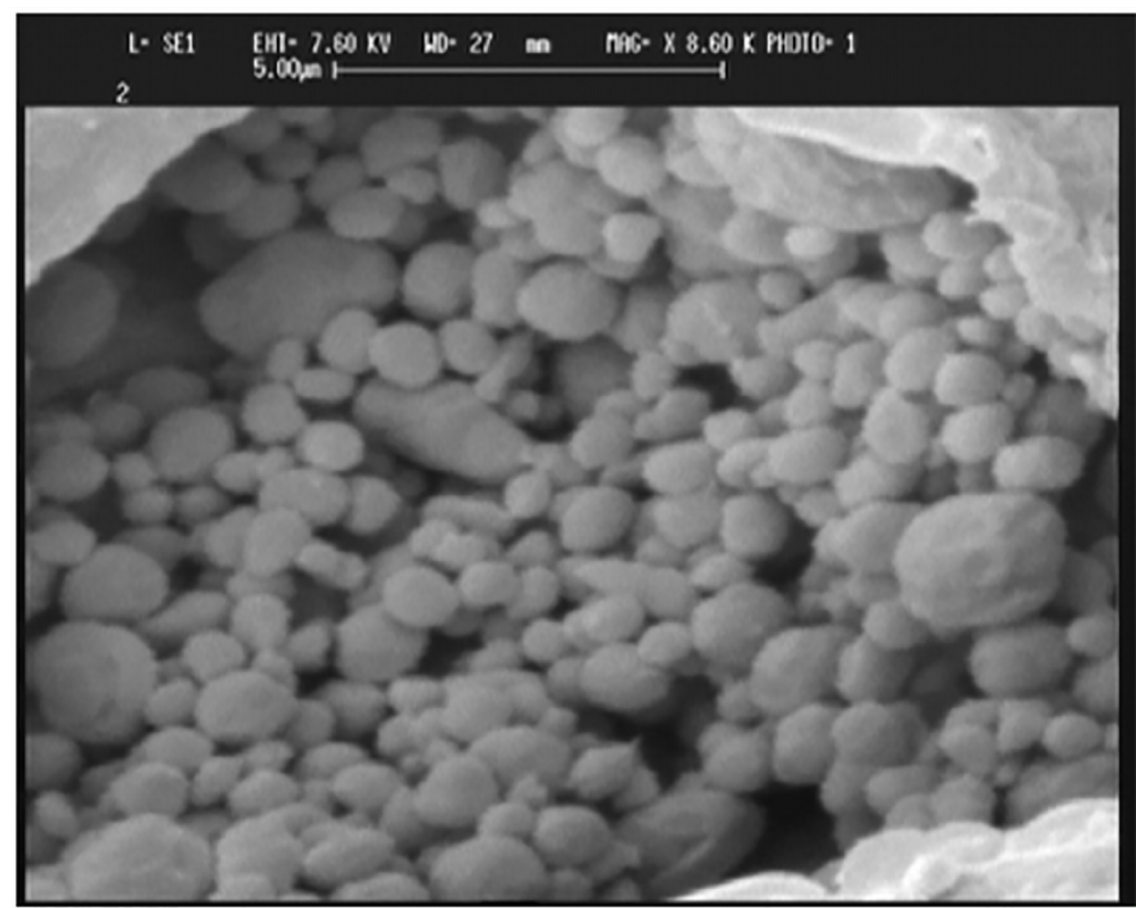

Figure 5. SEM image of Saccharomyces cerevisiae in $\mathrm{pH}=4$ and $\mathrm{DO} 5 \%$

\section{Discussion}

Today the introduction of safe and effective carriers is being considered. The carriers are highly desirable when they are natural, and cost little to produce. An efficient carrier should have a proper loading ability. Structurally, it should also have the ability to control the release of active ingredients well. Saccharomyces cerevisiae yeast cells as carriers have all the advantages mentioned above. With this vehicle, buying the expensive ingredients of a synthetic carrier is not necessary (10). By providing a suitable culture medium, millions of yeasts could be obtained to be used as carriers. The culture medium should prepare the best conditions for yeast growth to load the active materials in the best way. In order to provide suitable loading capacity and cell wall uniformity, growth of yeast cells was optimized. The $\mathrm{pH}$ and percentage DO are the two parameters which were optimized, to provide the best situation for yeast 
overgrowth. Several mathematical equations and software were studied to explain the yeast's growth process. Among these equations and software, the Richard growth equation and Matlab mathematical software were appropriate for our data. Yeast cell growth in different conditions was studied (Figures 1-2). It was proved that $\mathrm{pH}=4$ and $\mathrm{DO} 5 \%$ provided the best condition for yeast cells to reproduce and grow. This condition improved not only the yeast cells' reproduction and growth but also their size as carriers. In this situation, the growth curve showed a short lag phase (two hours). The log phase had the sharpest slope and lasted seven hours. At the end of log phase, the number of yeast cells reached $1.2 \times 109$ which was the maximum reproduction amount. UV/Visible absorptions at $600 \mathrm{~nm}$ also confirmed the results and it was at the maximum, about 1 , at the end of the $\log$ phase. Comparisons of different parameters which affect yeast cell growth were investigated. The results showed that yeast cells could reproduce better in lower $\mathrm{pH}$ and percentage DO. In three different amounts of percentage DO, by decreasing the acidity, the growth cycle decreased. Better growth in higher acidity conditions may be due to the ethanol metabolite of yeast cells. Acid neutralized the ethanol produced by the yeast cells and allowed them to continue their growth. Higher percentage $\mathrm{DO}$, in the same way as higher $\mathrm{pH}$, prevents yeast cell growth due to ethanol oxidation, which is a potent preventive factor for growth (17-19). As shown in the curves, the growth was improved in DO by $10 \%$, but when the results were fitted by Matlab software and the Richard equation, this misleading improvement was refused. Matlab software estimated the best equation to describe the growth pattern in every situation. In the first stage of the yeast cell growth cycle, absorptions were changed more than the numbers of yeast cells. In this situation, at first, the number of yeast cells was constant and only the yeasts and the buds originated from them continued growing. So the absorptions were increased without increase in the number of yeast cells. Among the various branches of generalized logistic equations, the Richard equation (Figure 3) was the equation best fitted to the results with a maximum correlation coefficient to calculate the maximum growth rate in each situation. The yeast cells reached the highest growth rate (3.309) in $\mathrm{pH}=4$ and $\mathrm{DO} 5 \%$ condition. In this condition, the longest time of the growth phase ( 7.8 hours) was obtained. Yeast cell size in this condition ( $\mathrm{pH}=4$ and DO $5 \%$ ) was estimated to be about $2 \times 3 \mu$ by light microscopy software (Figure 4). Again in this condition out of all the others, we found the biggest size for yeast cell for use as carriers in loading active materials. SEM images also confirmed the structural uniformity of yeast cells as carriers and the volume which is surrounded by the cell wall (Figure 5).

\section{Conclusions}

According to the results, the condition ( $\mathrm{pH}=4$ and $\mathrm{DO} 5 \%$ ) is the best growth condition for Saccharomyces cerevisiae to have the best morphological properties. The importance of these findings is that this yeast can be regarded as an efficient and affordable carrier. It is suggested that in future studies, different active ingredients are encapsulated in the yeasts as carriers and their effectiveness and stability be studied.

\section{Acknowledgments:}

This work was supported by a grant from School of Pharmacy, School of Persian and Complementary Medicine and the Vice Chancellor of Research at Mashhad University of Medical Sciences.

\section{Conflict of Interest:}

There is no conflict of interest to be declared.

\section{Authors' contributions:}

Both authors contributed to this project and article equally. Both authors read and approved the final manuscript.

\section{References:}

1) Feldmann H. Yeast: Molecular and Cell Biology. Wiley-Blackwell. 2010.

2) Walker LJ, Aldhous MC, Drummond HE, Smith BR, Nimmo ER, Arnott ID, et al. Anti-Saccharomyces cerevisiae antibodies (ASCA) in Crohn's disease are associated with disease severity but not NOD2/CARD15 mutations. Clin Exp Immunol. 2004; 135(3): 490-6. doi: 10.1111/j.13652249.2003.02392.x. PMID: 15008984, PMCID: PMC1808965.

3) Friedman N. The Friedman Lab Chronicles. Growing yeasts (Robotically). Nir Friedman Lab. 2011.

4) Herskowitz I. Life cycle of the budding yeast Saccharomyces cerevisiae. Microbiol Rev. 1988; 52(4): 53653. PMID: 3070323, PMCID: PMC373162.

5) Kaeberlein M, Powers RW, Steffen KK, Westman EA, Hu D, Dang N, et al. Regulation of yeast replicative life span by TOR and Sch9 in response to nutrients. Science. 2005; 310(5751): 1193-6. doi: 10.1126/science.1115535. PMID: 16293764. 
6) Kaeberlein M. Lessons on longevity from budding yeast. Nature. 2010; 464(7288): 513-9. doi: 10.1038/nature08981. PMID: 20336133, PMCID: PMC3696189.

7) Kraft P, Pharoah P, Chanock SJ, Albanes D, Kolonel LN, Hayes RB, et al. Genetic variation in the HSD17B1 gene and risk of prostate cancer. PLoS Genet. 2005; 1(5): 68. PMID: 16311626, PMCID: PMC1287955.

8) De Nobel JG, Klis FM, Munnik T, Priem J, Van Den Ende H. An assay of the relative cell wall porosity of Saccharomyces cerevisiae, Kluveromyces lactis and Schizosaccharomyces pombe. Yeast. 1990; 6(6): 48390. doi: 10.1002/yea.320060605. PMID: 2080665.

9) Sadeghi F, Torab M, Khattab M, Homayouni A, Afrasiabi Garekani H. Improvement of Physicomechanical Properties of Partially Amorphous Acetaminophen Developed from Hydroalcoholic Solution Using Spray Drying Technique. Iran J Basic Med Sci. 2013; 16(10): 1100-8. PMID: 24379968, PMCID: PMC3874097.

10) Shi G, Rao L, Yu H, Xiang H, Pen G, Long S, et al. Yeast-cell based microencapsulation of chlorogenic acid as a water-soluble antioxidant. J Food Eng. 2007; 80(4): 1060-7. doi: 10.1016/j.jfoodeng.2006.06.038.

11) Buis R. On the Generalization of the Logistic Law of Growth. Acta Biotheoretica. 1991; 39(3): 185-95. doi: 10.1007/BF00114174.

12) Marchetti C, Nakicenovic N. The Dynamics of Energy Systems and the Logistic Substitution Model. Int Inst For Appl Sys. Laxenburg, Austria. 1980.

13) Nelder JA. The fitting of a generalization of the logistic curve. Biometrics. 1961; 17: 89-110. doi: $10.2307 / 2527498$.

14) Tsoularis A, Wallace J. Analysis of logistic growth models. Math Biosci. 2002; 179(1): 21-55. PMID: 12047920 .

15) Turner ME Jr, Blumenstein BA, Sebaugh JL. A generalization of the logistic law of growth. Biometrics. 1969; 25(3): 577-80. doi: 10.2307/2528910. PMID: 5824407.

16) Richards OW. The Growth of the Yeast Saccharomyces cerevisiae. Ann Bot. 1928; 42(1): $271-83$.

17) Serrano R, Martín H, Casamayor A, Ariño J. Signaling alkaline pH stress in the yeast Saccharomyces cerevisiae through the Wsc1 cell surface sensor and the Slt2 MAPK pathway. J Biol Chem. 2006; 281(52): 39785-95. doi: 10.1074/jbc.M604497200. PMID: 17088254.

18) Salari R, Fazly Bazzaz BS, Rajabi O, Khashyarmanesh Z. New aspects of Saccharomyces cerevisiae as a novel carrier for berberine. DARU 2013; 21:73. DOI: 10.1186/2008-2231-21-73.

19) Salari R, Rajabi O, Khashyarmanesh Z, Fathi Najafi M, Fazly Bazzaz BS. Characterization of Encapsulated Berberine in Yeast Cells of Saccharomyces cerevisiae. Iran J Pharm Res 2015; 14(4): 1247-1256. PMid: 26664393, PMCid: PMC4673954 